\title{
The cytotoxic activities of the ethyl acetate and butanol crude extracts of marine cyanobacteria collected from Udar Island, Malaysia
}

\author{
Annisa Krisridwany*1, Tatsufumi Okino \\ ${ }^{1}$ School of Pharmacy, Department of Medicine and Health Sciences, \\ Universitas Muhammadiyah Yogyakarta, \\ Jl. Brawijaya, Bantul, Yogyakarta, Indonesia \\ ${ }^{2}$ Graduate School of Environmental Science, Faculty of Environmental Earth Science, \\ Hokkaido University, Sapporo 060-0810, Japan
}

Submitted: 19-02-2020

Reviewed: 04-03-2020

Accepted: 30-03-2020

\begin{abstract}
The ocean is abundant in organisms beneficial to living beings, including cyanobacteria that are widely studied for their bioactive compounds. This research was conducted to observe the compounds and concomitant cytotoxic activities of cyanobacteria in Udar Island waters, Sabah, Malaysia, against cancer cells. The samples were identified by the 16S DNA method, and a phylogenetic tree was built to check similarities in the genus. The samples were extracted using ethyl acetate and butanol. Afterward, the compounds were determined by Liquid ChromatographyMass Spectrometry (LCMS), while the cytotoxicity activities were examined by the MTT assay. Several known compounds in ethyl acetate crude extract, such as several types of Apratoxins, and possible new compounds were observed. The compounds examined were mainly peptide. The crude ethyl acetate extracts of Moorea sp. in Udar Island waters were found to contain cytotoxic compounds, with the $\mathrm{IC}_{50}$ value of $0.072 \mu \mathrm{g} / \mathrm{mL}$ against the MCF-7 breast cancer cell lines, that were more potent compared to the butanol crude extract, whose $\mathrm{IC}_{50}$ was $2.031 \mu \mathrm{g} / \mathrm{mL}$. Further isolation and cytotoxic tests are necessary to confirm which compounds are responsible as cytotoxic agents. This finding provides an opportunity for the discovery of anticancer compounds from marine cyanobacteria.
\end{abstract}

Keywords: marine cyanobacteria, Udar Island, Malaysia, LCMS, MTT assay, cytotoxicity

\footnotetext{
*Corresponding author:

Annisa Krisridwany

School of Pharmacy, Faculty of Medicine and Health Sciences

Universitas Muhammadiyah Yogyakarta

Jl. Brawijaya, Kasihan, Bantul, Yogyakarta, Indonesia

Email: akrisridwany@umy.ac.id
} 


\section{INTRODUCTION}

Cancer is one of the leading causes of death in the world with a continuously increasing number of cancer patients from year to year. Several types of cancer drugs are available for use, but some have side effects that are not well tolerated (Monsuez et al., 2010). Many scientists have been trying to discover or invent some other substances for cancer treatment. In the last few decades, numerous cancer drugs have been developed from natural ingredients, providing alternatives that expectedly give a better response (Gordaliza, 2007).

More than two thirds $(70 \%)$ of the Earth's surface is covered with water, creating a large habitat for marine organisms and a prolific source of organisms with high biological and chemical diversities. A countless number of marine organisms and marine biota are known to provide benefits to life. Marine organisms produce some specific chemical compounds to adapt to their environments and for their survival. For this reason, the compounds from marine natural products have been considered as potential sources of therapeutic agents to treat various diseases, including cancer (Newman and Cragg, 2016). Cytotoxic effects have been observed in, among others, marine sponges and marine tunicates (Reyes et al., 2008; Susilowati et al., 2019). Several derivatives even have been used clinically as medicine, e.g., trabectedin isolated from the Caribbean tunicate for the treatment of advance soft tissue sarcoma (D'Incalci et al., 2014) and ziconotide and eribulin mesylate derived from the substances isolated from marine organisms (De Negri et al., 2012; Gomes et al., 2016). An example of organisms that are diverse in chemical compounds is cyanobacteria (Uzair et al., 2012). Apratoxin A collected from marine cyanobacteria has been investigated for its bioactivities, for example, antibacterial, anticancer, antiparasitic, and antiviral (Luesch et al., 2001). Several bioactive compounds are very likely to be found in Cyanobacteria, especially from uncharted places in Malaysian waters. The Sarawak and Sabah states have a long coastline with high marine biodiversity that provides opportunities for researchers to explore more organisms and new beneficial compounds. This study was designed to identify the compounds contained in cyanobacteria living in unexplored Malaysian waters and observe their cytotoxic properties.

\section{MATERIALS AND METHODS \\ Materials}

The study used the QIAquick Poly Chain Reaction (PCR) purification kit (Diagen, Düsseldorf, Germany) to identify the sample and commercially synthesized primers (Invitrogen ${ }^{\mathrm{TM}}$ ). The PCR product was then checked with the ABI PRISM 3100 Sequence Detection System in the 3130xl Genetic Analyzer (Hitachi, Japan). The MCF-7 breast cancer cell line was used to test the cytotoxicity of the sample. Cisplatin (Sigma Aldrich) was used as the positive control.

\section{Methods}

\section{Sample collection}

The fresh mat-forming cyanobacteria was sampled from Udar Island, Malaysia, at the depth between 7 and $15 \mathrm{~m}$ (N6 ${ }^{\circ} 4^{\prime} 44^{\prime \prime}$, E1 $\left.16^{\circ} 5^{\prime} 10^{\prime \prime}\right)$ in March 2015. A small portion of the fresh sample was preserved in RNAlater ${ }^{\circledR}$ stabilization solution (Ambion, USA) for identification, while another portion of them was soaked in methanol for further extraction. Figure 1 is the underwater photograph of the cyanobacteria sample. 


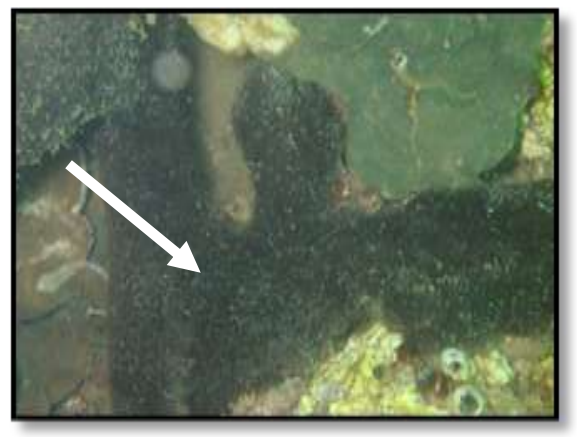

Figure 1. The underwater photograph of the research samples (Courtesy of Prof. Tatsufumi Okino)

\section{Sample identification}

The cyanobacteria sample was identified by molecular phylogenetic studies based on $16 \mathrm{~S}$ rRNA gene or 16S DNA sequence data with the method elaborated in Nübel et al. (1997). Firstly, the extraction solution was prepared to extract the DNAs. Secondly, the Poly Chain Reaction (PCR) was used to obtain the DNA sequence. The 16S DNA gene sequencing analysis has been reported as one of the methods suitable for the molecular genomic identification and phylogenetic classification of cyanobacteria (Wilmotte, 1994).

\section{Extraction and isolation}

The methanol crude extract was partitioned with ethyl acetate (EtOAc), butanol $(\mathrm{BuOH})$, and water $\left(\mathrm{H}_{2} \mathrm{O}\right)$ as part of the identification of lipophilic and hydrophilic compounds. The partitioned crude extracts were then checked by Liquid Chromatography-Mass Spectrometry (LCMS) at a concentration of $100 \mu \mathrm{g} / \mathrm{mL}$. This concentration was obtained by diluting the extracts with filtered ethanol, while the water fraction was diluted with water.

\section{Compound identification}

The chemical profiles of the sample were observed by the Electrospray Ionization (ESI) Liquid Chromatography-Mass Spectrometry (LCMS) with the Agilent 1100 Series HPLC system coupled to mass spectrometry (Brucker Daltonic, Germany) with the 2 x $150 \mathrm{~mm}$ Cadenza C18 column (USA). Eluent A was water added with $0.1 \%$ formic acid, and eluent B was acetonitrile $(\mathrm{MeCN})$ added with $0.1 \%$ formic acid at a flow rate of $0.2 \mathrm{~mL} / \mathrm{min}$. The elution gradient started with $50 \%$ of eluent B and increased to $80 \%$ in 15 minutes, then the isocratic condition of the $80 \%$ eluent B was allowed to stand for 15 minutes before going back to the initial condition within $0.1 \mathrm{~s}$.

\section{Cytotoxicity assay}

The sampled cyanobacteria was screened for cytotoxic activities by an in vitro MTT assay (Challouf et al., 2011; Li and Song, 2007). The MCF-7 cells were treated with the samples in different concentrations and incubated at $37^{\circ} \mathrm{C}$ with $5 \% \mathrm{CO}_{2}$ for 72 hours. The yellow MTT reagent was reduced to formazan (purple) by the metabolically active cells in the mitochondrial of the living cell. The formazan can be dissolved in DMSO (dimethyl-sulfoxide) organic solvent and has the optical density (OD) measurable at $570 \mathrm{~nm}$.

All of the experiments were conducted in Environmental Science Development Laboratory of Hokkaido University, Japan. 


\section{Data Analysis}

Sample identification

The phylogenetic analysis was conducted in MEGA 6 (Molecular Evolutionary Genetics Analysis version 6) by constructing a phylogenetic tree from the DNA sequence data using an optimality criterion, namely, maximum likelihood. Bootstrapping was performed with 1000 replicates.

\section{Compound identification}

The LCMS yielded the mass of every identified compound that was later checked against the MarinLit database.

\section{Cytotoxicity}

The MTT assay results of the crude extracts were compared to Cisplatin as the positive control. The cytotoxicity was determined from the ability of the compound to kill the cell lines, while the percent toxicity was measured by comparing the absorbances of the samples and blank at OD $570 \mathrm{~nm}$. The ethyl acetate and butanol crude extracts were tested for their cytotoxic activities at concentrations of $0.1,1,10$, and $100 \mu \mathrm{g} / \mathrm{mL}$. The $\mathrm{IC}_{50}$ values, which represent the ability of the extracts to remove $50 \%$ of the cell lines, were determined based on the graph of percent cytotoxicity against various concentrations of the crude extracts.

\section{RESULTS AND DISCUSSION Sample identification}

The cyanobacteria sample collected from Udar Island was identified as cyanobacteria belonging to the genus Moorea sp. Based on the phylogenetic tree (Figure 2), these samples were close to Moorea sp and Moorea bouillonii.

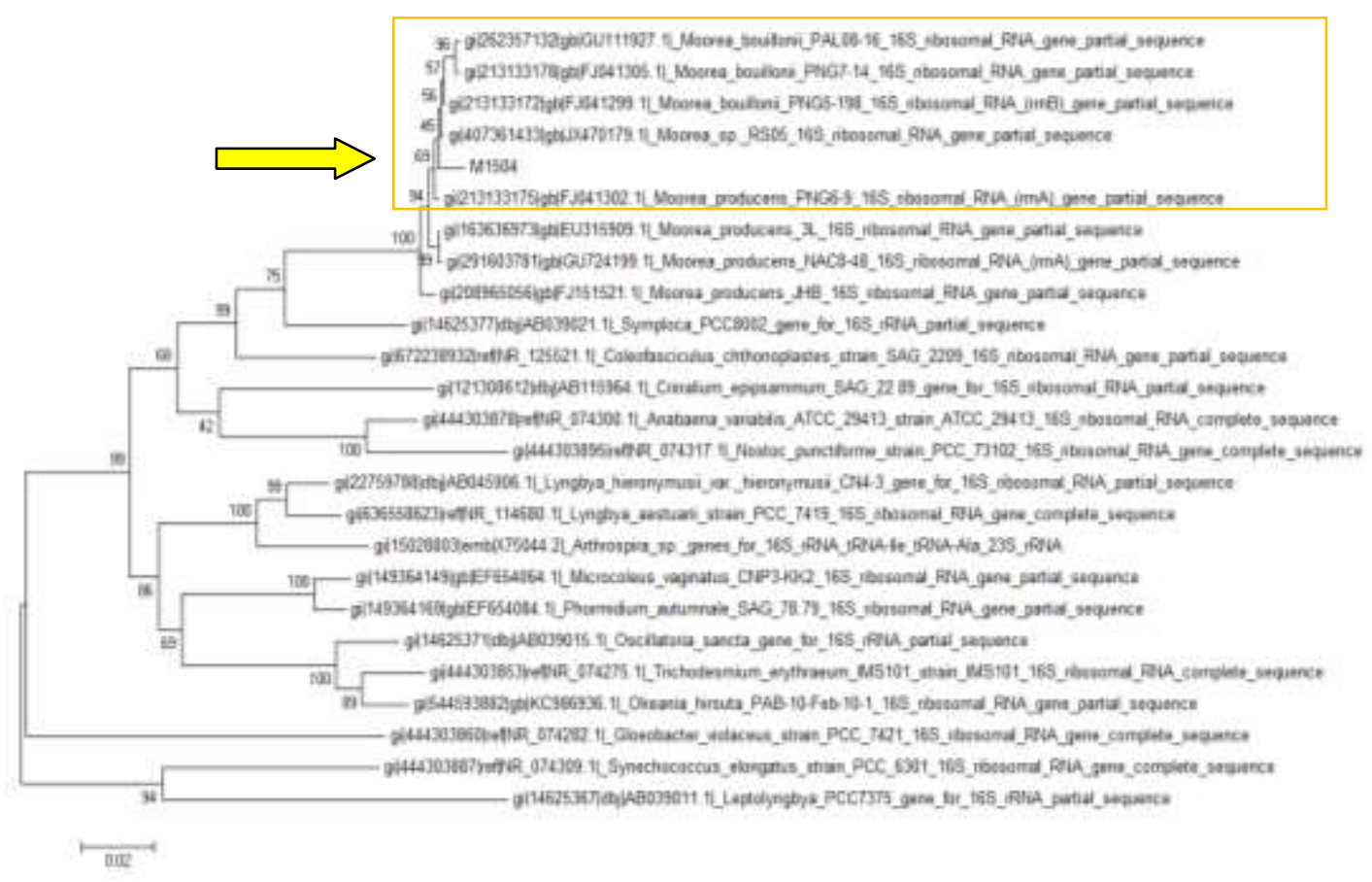

Figure 2. The phylogenetic tree of the marine cyanobacteria collected from Udar Island (M1504) 
According to Lopez et al. (2017), the marine cyanobacteria collected from Mantanani Island in Sabah, Malaysia, have been identified as Moorea bouillonii. Udar Island is located approximately $28 \mathrm{~km}$ from Kota Kinabalu, the capital city of Sabah, while Mantanani Island is located much further. Based on the morphology, the sample were mat-forming, which is typical of Moorea bouillonii. This finding shows that the marine cyanobacteria collected in the waters of Udar Island probably is similar to the ones found in Mantanani Island. However, further DNA analysis is still required to confirm the identity. The purity and quality of DNA are crucial in obtaining a good gene sequence.

\section{Extraction and isolation}

This step produced three parts of the crude extracts, namely, EtOAc, $\mathrm{BuOH}$, and $\mathrm{H}_{2} \mathrm{O}$ fractions with the respective masses of $330 \mathrm{mg}, 110 \mathrm{mg}$, and $3710 \mathrm{mg}$. The oily liquid forms were observed in the EtOAc dan $\mathrm{BuOH}$ fractions, and the salts were observed in the water fraction. The EtOAc and $\mathrm{BuOH}$ fractions were greenish, while the water fraction was light brownish.

\section{Identified Compounds}

Several secondary metabolites were observed from the LCMS result of the ethyl acetate fraction, as displayed in Figure 3. The LCMS results of the butanol and water fractions did not give a good chemical pattern, and, therefore, they are not discussed further. Based on the mass spectra presented in Table I, the ethyl acetate fraction was found to contain several known compounds, such as Apratoxins, Columbamide D, Wewakazole, and Laingolide B, and a possible new compound. Cyanobacteria in the genus Moorea have been studied as a rich source of novel bioactive compounds (Engene et al., 2012). The LCMS revealed that the Moorea sp. collected from Udar Island is rich in secondary metabolites, which are mainly peptides.

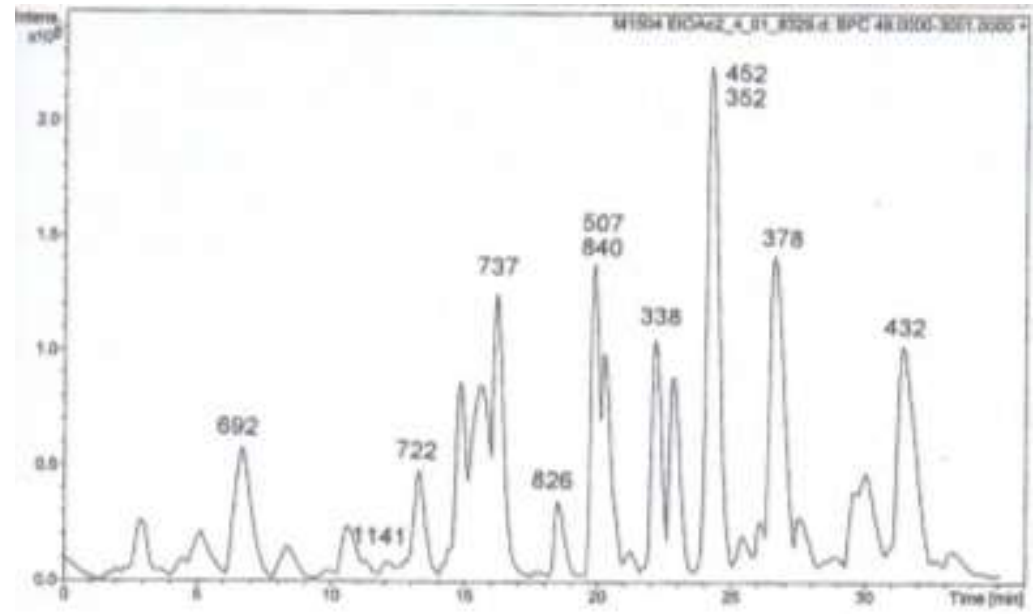

Figure 3. The chromatogram of the ethyl acetate fraction of marine cyanobacteria collected from Udar Island, as produced by the LCMS

The observed mass of Apratoxin A from the sample was similar to the Moorea bouilonii samples collected from Guam, Palau, Papua New Guinea, and Malaysia (Lopez et al., 2017; Matthew et al., 2010; Tan et al., 2013). In other words, Apratoxin A has been frequently observed from Moorea bouilonii samples. The previous research of Moorea bouilonii in Mantanani Island confirms the presence of Apratoxin A, Apratoxin C, Wewakazole, and Columbamide, specifically Columbamide D and Columbamide E (Lopez et al., 2017). In the present study, these compounds were also observed, except for Columbamide E. This finding reveals how different environments may affect the secondary metabolites of the organisms. The cyanobacteria collected from Udar Island contain a possible new compound (number 6 in Table I) based on the observation of the 
exact mass on the MarinLit database. Further isolation of the selected possible new compound is necessary to confirm its exact identity, preferably through nuclear magnetic resonance (NMR) analysis.

Table I. Several known compounds observed by their respective mass that describe the samples of marine cyanobacteria collected from Udar Island

\begin{tabular}{cccc}
\hline Retention & Observed & Compounds & Structures \\
time $(\min )$ & mass $(\mathbf{M}+\mathbf{H})$ & &
\end{tabular}

7

692.3146

Ulongamide C

$\mathrm{C}_{36} \mathrm{H}_{45} \mathrm{~N}_{5} \mathrm{O}_{7} \mathrm{~S}$

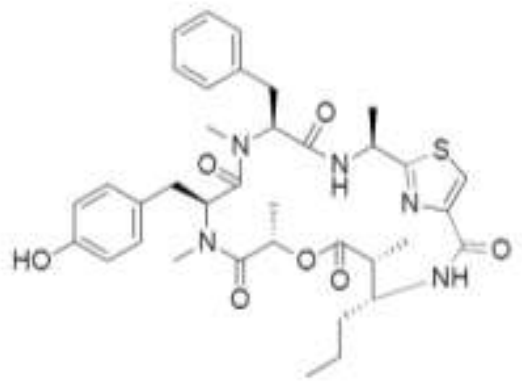

Wewakazole

11

1141.5349

$\mathrm{C}_{59} \mathrm{H}_{72} \mathrm{~N}_{12} \mathrm{O}_{12}$

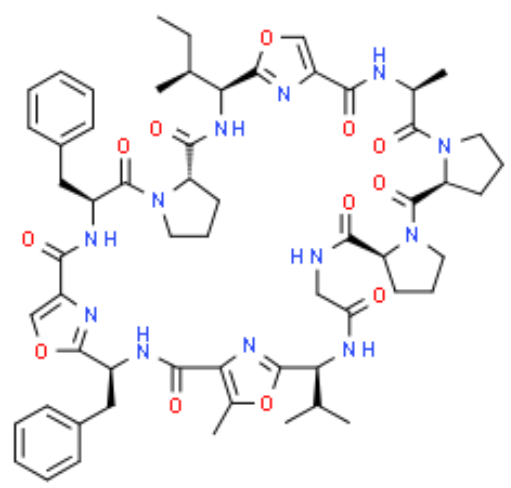

Lyngbyapeptin B

$\mathrm{C}_{38} \mathrm{H}_{51} \mathrm{~N}_{5} \mathrm{O}_{7} \mathrm{~S}$

13

722.3627

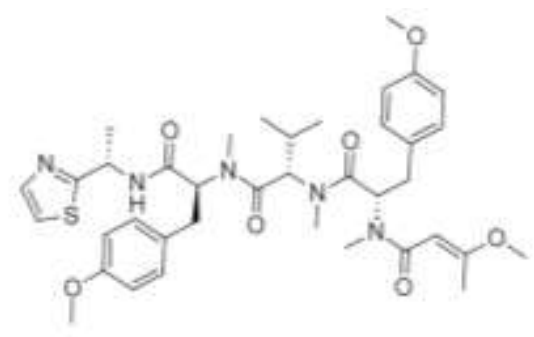

Pharmaciana Vol. 10, No. 1, March 2020, Page. 23- 34 


$\begin{array}{cccc}\text { Retention } & \text { Observed } & \text { Compounds } & \text { Structures } \\ \text { time }(\min ) & \text { mass }(\mathbf{M}+\mathbf{H}) & & \end{array}$

Hantupeptin A

16.2

737.4464

$\mathrm{C}_{41} \mathrm{H}_{60} \mathrm{~N}_{4} \mathrm{O}_{8}$

826.4841

Apratoxin C

$\underline{\mathrm{C}}_{4} \underline{4} \underline{\mathrm{H}}_{67} \underline{\mathrm{N}_{5}} \underline{\mathrm{O}}_{8} \underline{\mathrm{S}}$

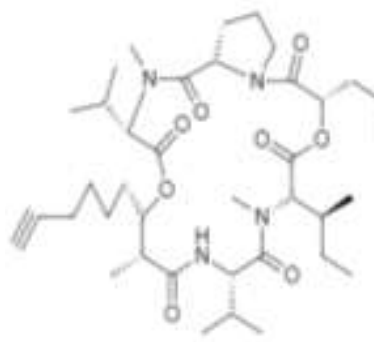

20

$\mathbf{5 0 7 . 3 8 2 7}$

New compound

New compound

Apratoxin A

20

840.5006

$\boldsymbol{C}_{45} \mathrm{H}_{69} \mathrm{~N}_{5} \mathrm{O}_{8} \mathrm{~S}$
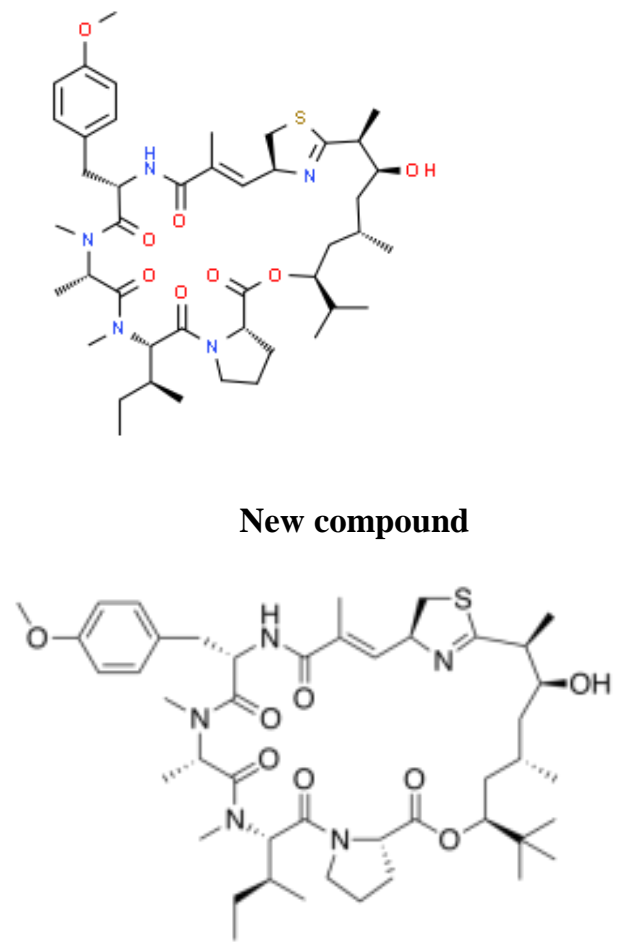

Laingolide $\mathrm{A}$

$\mathrm{C}_{20} \mathrm{H}_{35} \mathrm{NO}_{3}$

22.1

338.2674

or palmyrolide A

$$
\mathrm{C}_{20} \mathrm{H}_{35} \mathrm{NO}_{3}
$$




\begin{tabular}{|c|c|c|c|}
\hline $\begin{array}{l}\text { Retention } \\
\text { time (min) }\end{array}$ & $\begin{array}{c}\text { Observed } \\
\text { mass }(\mathbf{M}+\mathbf{H})\end{array}$ & Compounds & Structures \\
\hline
\end{tabular}
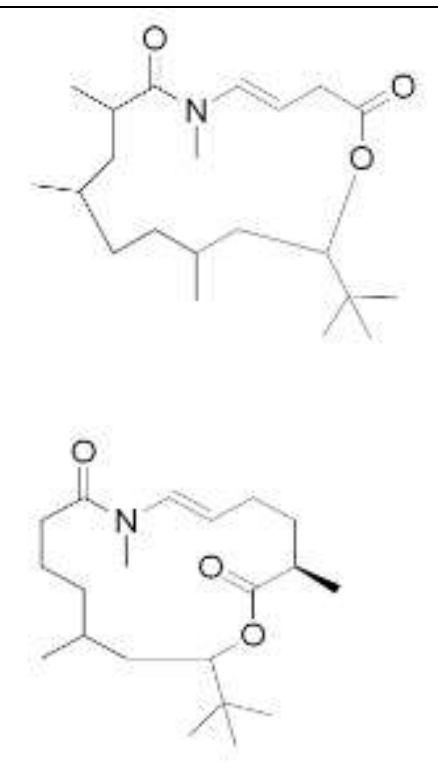

Columbamide D $\mathrm{C}_{23} \mathrm{H}_{43} \mathrm{Cl}_{2} \mathrm{NO}_{3}$
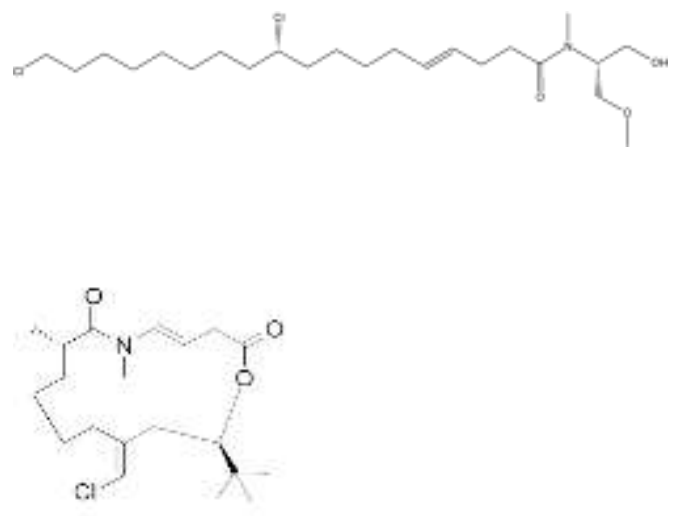

Madangolide

27

378.3005

$\mathrm{C}_{23} \mathrm{H}_{39} \mathrm{NO}_{3}$

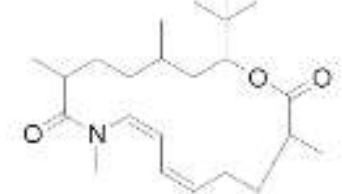

\section{Cytotoxicity}

Various concentrations of the ethyl acetate and butanol crude extracts were tested against MCF-7 breast adenocarcinoma cancer cells. Figure 4 shows the log concentrations on the horizontal axis and the percentage of dead cells on the vertical axis. Then, the $\mathrm{IC}_{50}$ values were determined by the linear regression. Based on the results, the linearity of the ethyl acetate crude 
extract (EtOAc) was not acceptable, as evidenced by $\mathrm{R}^{2}=0.506$. As determined with the linear regression equation, the $\mathrm{IC}_{50}$ of the ethyl acetate crude extracts was $0.072 \mu \mathrm{g} / \mathrm{mL}$. Since the percent cytotoxicity from the experiment increased significantly from 0.1 to $1 \mu \mathrm{g} / \mathrm{mL}$, more testing of cytotoxicity between the two concentrations is highly suggested. Compared to Cisplatin, the cytotoxicity of the ethyl acetate crude extract was higher. This result was probably due to the presence of known Apratoxins (Apratoxin A and Apratoxin C), which are cytotoxic even at the nano level (Luesch et al., 2001).

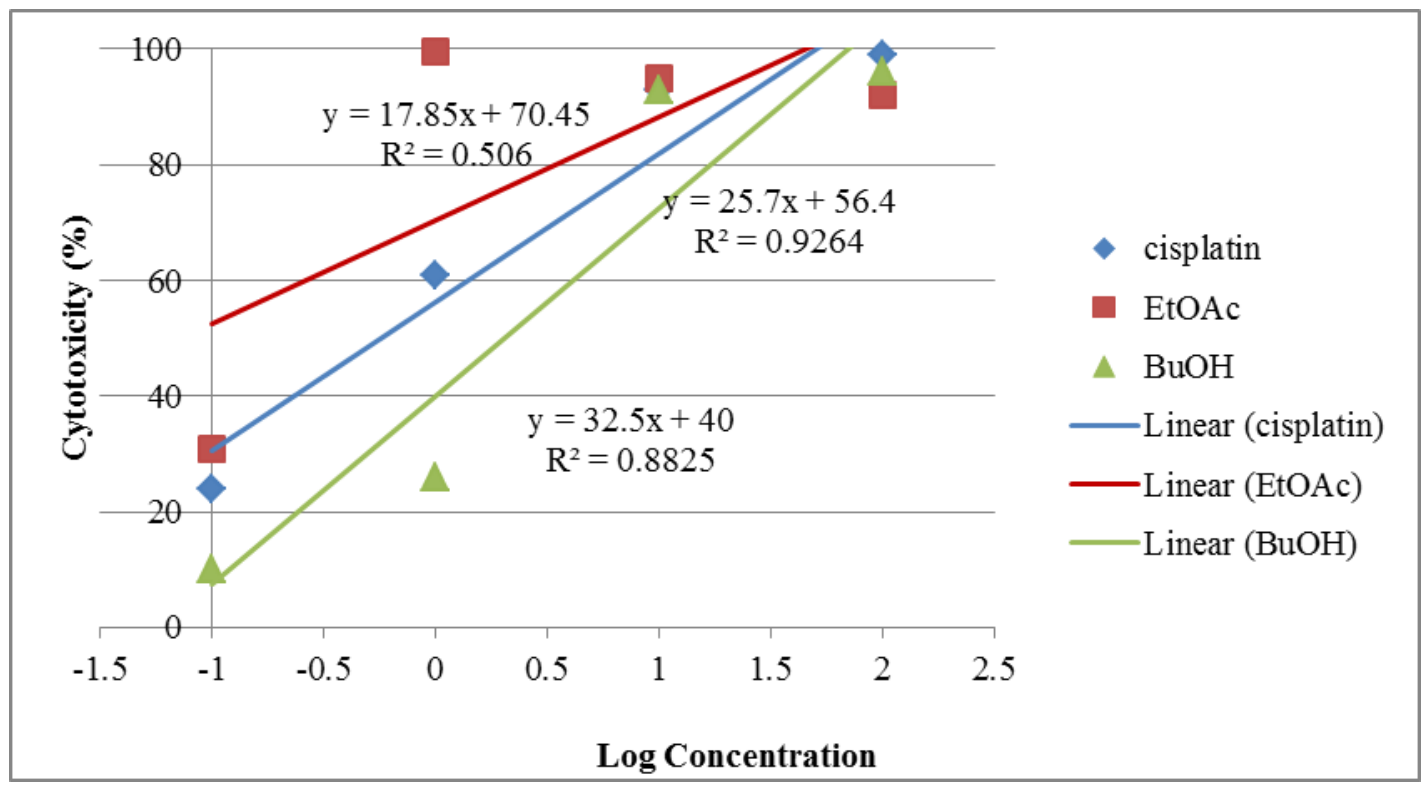

Figure 4. The MTT assay results of the ethyl acetate (EtOAc) and butanol $(\mathrm{BuOH})$ crude extracts of marine cyanobacteria collected from Udar Island against MCF-7 breast cancer cells with cisplatin as the positive control

As seen in Table II, the butanol crude extract exhibited adequate cytotoxic activities at the concentration of $10 \mu \mathrm{g} / \mathrm{mL}$ upwards. The $\mathrm{IC}_{50}$ value of this extract was $2.031 \mu \mathrm{g} / \mathrm{mL}$. This finding indicates that the ethyl acetate fraction is more potent compared to the butanol fraction.

Table II. The observed cytotoxic activities of the ethyl acetate and butanol crude extracts of marine cyanobacteria collected from Udar Island

\begin{tabular}{|c|c|c|c|c|c|}
\hline \multirow[t]{2}{*}{ Extracts } & \multicolumn{4}{|c|}{ \% Cytotoxicity at Concentration } & \multirow[t]{2}{*}{$\mathrm{IC}_{50}(\mu \mathrm{g} / \mathrm{mL})$} \\
\hline & $0.1 \mu \mathrm{g} / \mathrm{mL}$ & $1 \mu \mathrm{g} / \mathrm{mL}$ & $10 \mu \mathrm{g} / \mathrm{mL}$ & $100 \mu \mathrm{g} / \mathrm{mL}$ & \\
\hline Cisplatin & 24 & 61 & 93 & 99 & 0.564 \\
\hline Ethyl Acetate & 31 & 99.5 & 95 & 92 & 0.072 \\
\hline Butanol & 10 & 26 & 93 & 96 & 2.031 \\
\hline
\end{tabular}

Further assays must be completed to analyze the target compounds in the ethyl acetate fraction. For this reason, the mechanism through which the cytotoxic compounds act must be investigated more. However, several compounds have been reported to inhibit cell growth in a variety of cancer lines and induce cell death by apoptosis (Costa et al., 2012). 


\section{CONCLUSION}

Cyanobacteria in the genus Moorea sp. in the waters of Udar Island, Malaysia, contain many chemical compounds and a possible new compound in their ethyl acetate fraction, as confirmed by the observed mass. Compared to the butanol crude extract, the ethyl acetate crude extract is more potent, with the $\mathrm{IC}_{50}$ value of $0.072 \mu \mathrm{g} / \mathrm{mL}$. Further isolation, purification, and analysis are required to clarify the specific compounds. The compounds isolated from Moorea sp. can be a new source from marine natural products to develop a new anticancer agent.

\section{ACKNOWLEDGMENT}

We are grateful to the staffs from Institute for Tropical Biology and Conservation, Universiti Malaysia Sabah for the assistance during the field sample collection. We are grateful to Dr. M. Kurasaki, and Dr. K. Washio, Graduate School of Environmental Science, Hokkaido University for the facilities to do cell culture, the assay, and sample identification. We would also like to thank Dr. Julius Lopez for his guidance to do the 16S DNA analysis.

\section{REFERENCES}

Challouf, R., Trabelsi, L., Ben Dhieb, R., El Abed, O., Yahia, A., Ghozzi, K., Ben Ammar, J., Omran, H., and Ben Ouada, H., 2011, Evaluation of cytotoxicity and biological activities in extracellular polysaccharides released by cyanobacterium Arthrospira platensis, Brazilian Archives of Biology and Technology, 54(4): 831-838.

Costa, M., Costa-Rodrigues, J., Fernandes, M.H., Barros, P., Vasconcelos, V., and Martins, R., 2012, Marine Cyanobacteria Compounds with Anticancer Properties: A Review on the Implication of Apoptosis, Marine Drugs, 10(10): 2181-2207.

De Negri, P., Tirri, T., S, M., and Papa, A., 2012, Intrathecal ziconotide for cancer pain relief: When, how and why, Journal of Anesthesia and Clinical Research, 3(8): 227-228.

D’Incalci, M., Badri, N., Galmarini, C.M., Allavena, P., 2014, Trabectedin, a drug acting on both cancer cells and the tumour microenvironment, British Journal of Cancer, 111(4): 646650.

Engene, N., Rottacker, E.C., Kaštovský, J., Byrum, T., Choi, H., Ellisman, M.H., Komárek, J., and Gerwick, W.H., 2012, Moorea producens gen. nov., sp. nov. and Moorea bouillonii comb. nov., tropical marine cyanobacteria rich in bioactive secondary metabolites, International Journal of Systematic and Evolutionary Microbiology, 62(5): 1171-1178.

Gomes, N.G.M., Dasari, R., Chandra, S., Kiss, R., Kornienko, A., 2016, Marine Invertebrate Metabolites with Anticancer Activities: Solutions to the "Supply Problem." , Marine Drugs, 14(5):98-137.

Gordaliza, M., 2007, Natural products as leads to anticancer drugs, Clinical and Translational Oncology, 9(12): 767-776.

Li, J., Song, L., 2007, Applicability of the MTT assay for measuring viability of cyanobacteria and algae, specifically for Microcystis aeruginosa (Chroococcales, Cyanobacteria), Phycologia 46(5): 593-599.

Lopez, J.A.V., Petitbois, J.G., Vairappan, C.S., Umezawa, T., Matsuda, F., and Okino, T., 2017. Columbamides D and E: Chlorinated Fatty Acid Amides from the Marine Cyanobacterium Moorea bouillonii Collected in Malaysia, Organic Letters, 19(16): 4231-4234.

Luesch, H., Yoshida, W.Y., Moore, R.E., Paul, V.J., and Corbett, T.H., 2001, Total structure determination of apratoxin A, a potent novel cytotoxin from the marine cyanobacterium Lyngbya majuscula, Journal of The American Chemical Society, 123(23): 5418-5423.

Matthew, S., Salvador, L.A., Schupp, P.J., Paul, V.J., and Luesch, H., 2010, Cytotoxic Halogenated Macrolides and Modified Peptides from the Apratoxin-Producing Marine Cyanobacterium Lyngbya bouillonii from Guam, Journal of Natural Products, 73(9): 1544-1552. 
Monsuez, J.J., Charniot, J.C., Vignat, N., and Artigou, J.Y., 2010, Cardiac side-effects of cancer chemotherapy, International Journal of Cardiology, 144(1): 3-15.

Newman, D.J., Cragg, G.M., 2016, Natural Products as Sources of New Drugs from 1981 to 2014, Journal of Natural Products, 79(3): 629-661.

Nübel, U., Garcia-Pichel, F., and Muyzer, G., 1997, PCR primers to amplify 16S rRNA genes from cyanobacteria, Applied and Environmental Microbiology, 63(8): 3327-3332.

Reyes, F., Fernández, R., Rodríguez, A., Francesch, A., Taboada, S., Ávila, C., and Cuevas, C., 2008, Aplicyanins A-F, new cytotoxic bromoindole derivatives from the marine tunicate Aplidium cyaneum, Tetrahedron, 64(22): 5119-5123.

Susilowati, F., Swasono, R., Okino, T., and Haryadi, W., 2019, In Vitro Cytotoxic Anticancer Potential of Bioactive Fraction Isolated From Indonesian Tidal Sponge Calthropella sp., Asian Journal of Pharmaceutical Clinical Research, 12(1): 380-383.

Tan, L.T., Okino, T., and Gerwick, W.H., 2013, Bouillonamide: A Mixed Polyketide-Peptide Cytotoxin from the Marine Cyanobacterium Moorea bouillonii, Marine Drugs, 11(8): 3015-3024.

Uzair, B., Tabassum, S., Rasheed, M., and Rehman, S.F., 2012, Exploring Marine Cyanobacteria for Lead Compounds of Pharmaceutical Importance, The Scientific World Journal, 2012:110.

Wilmotte, A., 1994, Molecular Evolution and Taxonomy of the Cyanobacteria, In Bryant, D.A. (Ed.), The Molecular Biology of Cyanobacteria, Advances in Photosynthesis. Netherlands: Springer, 1-25. 
